\title{
Characterization of gelatins from Nile tilapia skins preserved by freezing and salting
}

\section{Caracterização das gelatinas obtidas a partir de peles de tilápia do Nilo conservadas pelos métodos de congelamento e salga}

\author{
Adriana Cristina Bordignon ${ }^{1 *}$; Maria Luiza Rodrigues de Souza ${ }^{2}$; \\ Eliane Gasparino²; Edson Minoru Yajima³; Jesuí Vergílio Visentainer; \\ Elenice Souza dos Reis Goes ${ }^{5}$
}

\begin{abstract}
After Nile tilapia skin was preserved using the methods of freezing and dry salting, characteristics of skin gelatin were evaluated with regard to yield, rheological features and physical and chemical properties. Preservation was performed after filleting, at which time skins were either frozen $\left(-18^{\circ} \mathrm{C}\right)$ for 7 days or salted $\left(25^{\circ} \mathrm{C}\right)$ for 7 days. Although no differences $(p>0.05)$ were observed with respect to humidity, protein, lipid, ash and calcium levels, gelatin from salted skins had a higher concentration of iron relative to frozen skins. Further, twenty-three fatty acids were detected in salted skins compared with merely three found in skin derived gelatin. Of amino acids found, glycine, alanine, proline and arginine were the most abundant. Hydroxyproline abundance in salted and frozen skin gelatin were $8.76 \%$ and $8.71 \%$, respectively. In addition, salted skin gelatins had a greater accumulation of saturated fatty acids and lower rates of monounsaturated fatty acids. Salted skin gelatin had the highest yield $\left(18 \mathrm{~g} \times 100 \mathrm{~g}^{-1}\right)$, gel strength $(200 \mathrm{~g})$ and viscosity $(19.02 \mathrm{mPas})$ when compared to the yield $\left(17 \mathrm{~g} \times 100 \mathrm{~g}^{-1}\right)$, gel strength $(12.7 \mathrm{~g})$ and viscosity $(9.16 \mathrm{mPas})$ of frozen skins. Results show that gelatin from dry salted skin had the best yield and also had relatively better rheological properties, more iron, and better coloration relative to gelatin obtained from frozen skins of Nile tilapia.
\end{abstract}

Key words: Gelatin from fish skin. Amino acid profile. Gel strength. Oreochromis niloticus.

\section{Resumo}

O objetivo deste estudo foi avaliar os métodos de conservação de peles de tilápia do Nilo (por congelamento e salga a seco) sobre o rendimento, propriedades reológicas e físico-químicas da gelatina obtida a partir destas peles. Para tanto, após a filetagem, peles de tilápia foram distribuídas em dois

${ }^{1}$ Prof ${ }^{a}$, Curso de Engenharia de Pesca, Universidade Federal do Maranhão, UFMA, Pinheiro, MA, Brasil. E-mail: adriana. bordignon@hotmail.com

2 Prof $^{\text {as }}$. Departamento de Zootecnia, Universidade Estadual de Maringá, UEM, Maringá, PR, Brasil. E-mail: mlrsouzauem@ gmail.com; gasparinoeliane@gmail.com

3 Prof., Curso de Engenharia de Produção, Pontifícia Universidade Católica do Paraná, PUCPR, Londrina, PR, Brasil. E-mail: edson_yajima@hotmail.com

4 Prof., Departamento de Química, UEM, Maringá, PR, Brasil. E-mail: jesuiv@gmail.com

5 Profa, Faculdade de Ciências Agrárias, Universidade Federal da Grande Dourados, UFGD, Dourados, MS, Brasil. E-mail: elenicesreis@yahoo.com.br

* Author for correspondence 
métodos de conservação: peles congeladas $\left(-18^{\circ} \mathrm{C}\right)$ por 7 dias e peles salgadas $\left(25^{\circ} \mathrm{C}\right)$ por 7 dias. Não foram observadas diferenças $(\mathrm{P}>0,05)$ nos teores de umidade, proteína, lipídeos, cinzas e cálcio entre gelatinas; porém a gelatina de peles salgadas apresentou maior teor de ferro. Foram encontrados 23 ácidos graxos nas peles e apenas três nas gelatinas, sendo que gelatinas de peles salgadas apresentaram maior somatório de ácidos graxos saturados e menor de ácidos graxos monoinsaturados. Os aminoácidos encontrados em maiores proporções foram glicina, alanina, prolina e arginina, sendo que os valores de hidroxiprolina encontrados para a gelatina de pele salgada foi de $8,76 \mathrm{~g} \times 100 \mathrm{~g}^{-1}$ e na gelatina de peles

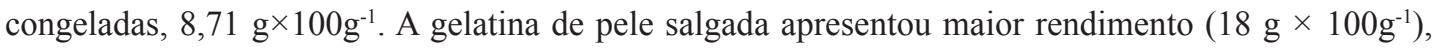
força de gel $(200 \mathrm{~g})$ e viscosidade $(19,02 \mathrm{mPas})$ em relação a gelatina de pele congelada $\left(17 \mathrm{~g} \times 100 \mathrm{~g}^{-1}\right.$, $12,7 \mathrm{~g}$ e $9,16 \mathrm{mPas})$. Conclui-se que a gelatina extraída a partir de peles conservadas pela salga a seco apresentou melhor rendimento, melhoria nas propriedades reológicas, maior teor de ferro e melhor coloração, em relação a gelatina obtida de peles congeladas de tilápia do Nilo.

Palavras-chave: Gelatina de pele de peixe. Perfil de aminoácidos. Força de gel. Oreochromis niloticus.

\section{Introduction}

Gelatin is a common polymers and is widely utilized in food, pharmaceutical and cosmetic industries, due to its functional and technological properties (KARIM; BHAT, 2009). Approximately $95 \%$ of commercial gelatin is derived from mammals, mainly from pig and cow hides. The other $5 \%$ comes from the bones of these animals (TABARESTANI et al., 2010), even though several social and cultural mores limit the consumption of gelatin derived from swine and cattle (KARIM; BHAT, 2009). Fish skin may serve as an alternative source of gelatin used commercially. Further, it has received a lot of attention as an alternative to bovine sources of gelatin due to the occurrence of bovine spongiform encephalopathy (HOSSEINI et al., 2013) and foot-and-mouth disease, both which cause severe harm to humans (CHO et al., 2005).

The production of gelatin from fish skin is attractive because it is an important byproduct of the fish industry (HOSSEINI et al., 2013). Fish gelatin is different when compared to gelatin derived from mammals, mainly because the melting point of fish gelatin is lower. This results in fish gelatin dissolving quickly in the mouth without requiring chewing (KARIM; BHAT, 2009). The characteristics of gelatins and their resulting applications are affected by factors including collagen features of the prime matter, type of pre-treatment, extraction process and skin preservation methods (JOHNSTON-BANKS, 1990).
Mammal collagen is more stable and has greater preservation efficiency than fish-extracted collagen, which is more likely to deteriorate (FERNÁNDEZDÍAZ et al., 2003; GIMÉNEZ et al., 2005a; TABARESTANI et al., 2010). Fast microbial degradation and losses occur after the filleting and skin removal processes through the autolytic activities of proteases in the skin (GIMÉNEZ et al., 2005a; LIU et al., 2010) as a part of the process of collagen hydrolysis (INTARASIRISAWAT et al., 2007). Throughout the process, collagen is broken down into simple structures, and, subsequently, a loss of quality in prime matter occurs, reducing the final quality of the gelatin (FERNÁNDEZ-DÍAZ et al., 2003; LIU et al., 2008). Further studies on the different methods of fish skin preservation will be required to establish a method resulting in gelatins of higher stability that maintains commercially attractive properties throughout the extraction process.

The present work evaluated two currently utilized preservation methods for treating tilapia skins, freezing and dry salting. Analysing yield, and the rheological, physical and chemical properties of gelatin derived from fish skins treated by these methods.

\section{Materials and Methods}

Raw skins of Nile tilapia (Oreochromis niloticus) were used. Fish (weighting between $600 \mathrm{~g}$ and $800 \mathrm{~g}$ ) 
were caught in earth tanks, stunned in a solution of ice water and slaughtered by cutting at the gills by the staff of the fish farm. Tissue residues were removed manually by trained employees of the farm. The raw material was refrigerated upon arrival at the laboratory. Skins were packed in ice coolers during the cleaning process. The skins were weighed and distributed in two treatment groups corresponding to the method used to preserve the skins. Group one was designated the freezing treatment set and group two would be preserved by dry salting. For each treatment, $3 \mathrm{~kg}$ of skin was processed.

During the cleaning of skins, temperature was maintained at $0-5^{\circ} \mathrm{C}$ for skins that would be later frozen and around $25^{\circ} \mathrm{C}$ for skins that would be later salted. Clean skins and solid wastes were weighted. Batches of skins from group one were frozen at $-18^{\circ} \mathrm{C}$, whereas skins for salting were maintained at $\pm 25^{\circ} \mathrm{C}$ for seven days. The salting process was carried out in perforated plastic trays alternating layers of skin and salt at a ratio of salt:skin equal to $1: 6(\mathrm{w} / \mathrm{v})$.

Frozen skins were thawed in a refrigerator for $12 \mathrm{~h}$ and salted skins were desalted by four, 10 min washes. To wash, each batch was washed for $10 \mathrm{~min}$, weighed and immersed in water at a ratio of raw material/water of $1: 6(\mathrm{w} / \mathrm{v})$ at $24^{\circ} \mathrm{C} \pm 2{ }^{\circ} \mathrm{C}$. Further, $\mathrm{pH}$ was adjusted between 2.8 and 3.2 with $10 \mathrm{~N} \mathrm{H}_{2} \mathrm{SO}_{4}$ for $1 \mathrm{hr}$. The skins were then washed with tap water and a skin sample was used for the boiling test which checks the skin's internal $\mathrm{pH}$ (ZHANG et al., 2005).

Gelatin extraction was performed as previously described in Bordignon et al. (2012). After pH stabilization (between 4.8 and 5.2) was reached, gelatin was extracted in a water bath for an hour at $50^{\circ} \mathrm{C} \pm 2{ }^{\circ} \mathrm{C}$. The concentration of total solids was measured with digital refractometer (Atago 0-85\% Brix). After extraction, both the gelatin solution and the non-dissolved skins were filtered through a Buchner funnel with wet cellulose pulp $(20 \mathrm{~mm})$ and Whatman filter paper n.4. A sample was taken to use for molecular profiling. The remaining solution was concentrated in a multistage evaporator to remove part of the water present in the gelatin solution, which was later gelled, ground and dried in a forced air dryer at $25^{\circ} \mathrm{C}$ for 24 hours and then at $50^{\circ} \mathrm{C}$ for 4 hours (Figure 1).

Gelatin extraction yield was calculated by the ratio proposed by Nagarajan et al. (2012) as shown in the following equation:

$$
\text { Yield }(\%)=\frac{\text { Weight of dried gelatin }(\mathrm{g})}{\text { Weight of dry skin }(\mathrm{g})} \times 100
$$

After seven days, frozen and salted skins coupled to dry gelatin were analyzed to measure moisture, protein, ash, minerals, amino acids, fatty acids and hydroxyproline levels. Approximate composition of moisture, protein, ash and fat were determined by AOAC methods (2005). Ca and Fe levels were analyzed following Eijsink et al. (1997) using an atomic absorption spectrophotometer with flame atomization (AA240FS - VARIAN).

Gelatin $\mathrm{pH}$ was measured using a concentrated solution of $6.67 \%$ gelatin dissolved in $100 \mathrm{ml}$ of deionized water with a $\mathrm{pH}$-meter (Model FE 20K, Mettler Toledo). Total lipids were extracted following method described by Bligh and Dyer (1959) and trans-esterified according to ISO methodology (1978), with separation by gas chromatography. A $2.0 \mu \mathrm{L}$ aliquot was injected into the fused-silica capillary column CP-7420 (Select FAME) $(100 \mathrm{~m} \times 0.25 \mathrm{~mm}$ i.d. x $0.25 \mu \mathrm{m}$ of cyanopropyl) at $165^{\circ} \mathrm{C}$ for $18 \mathrm{~min}$ and increased to $235^{\circ} \mathrm{C}$ for $24.5 \mathrm{~min}$.

Fatty acids were identified by comparing retention times with Sigma standards (USA) through co-elution spiking of the standard with sample rates and comparing to Equivalent Chain Length (ECL). Percentage of fatty acids was determined by integration of peak areas using the Software Varian Workstation Star 5.0 and data was given as relative area percentages (STRÁNSKY et al., 1997). 
Figure 1. Flowchart outlining the procedure used for the extraction of gelatin from Nile tilapia skins.

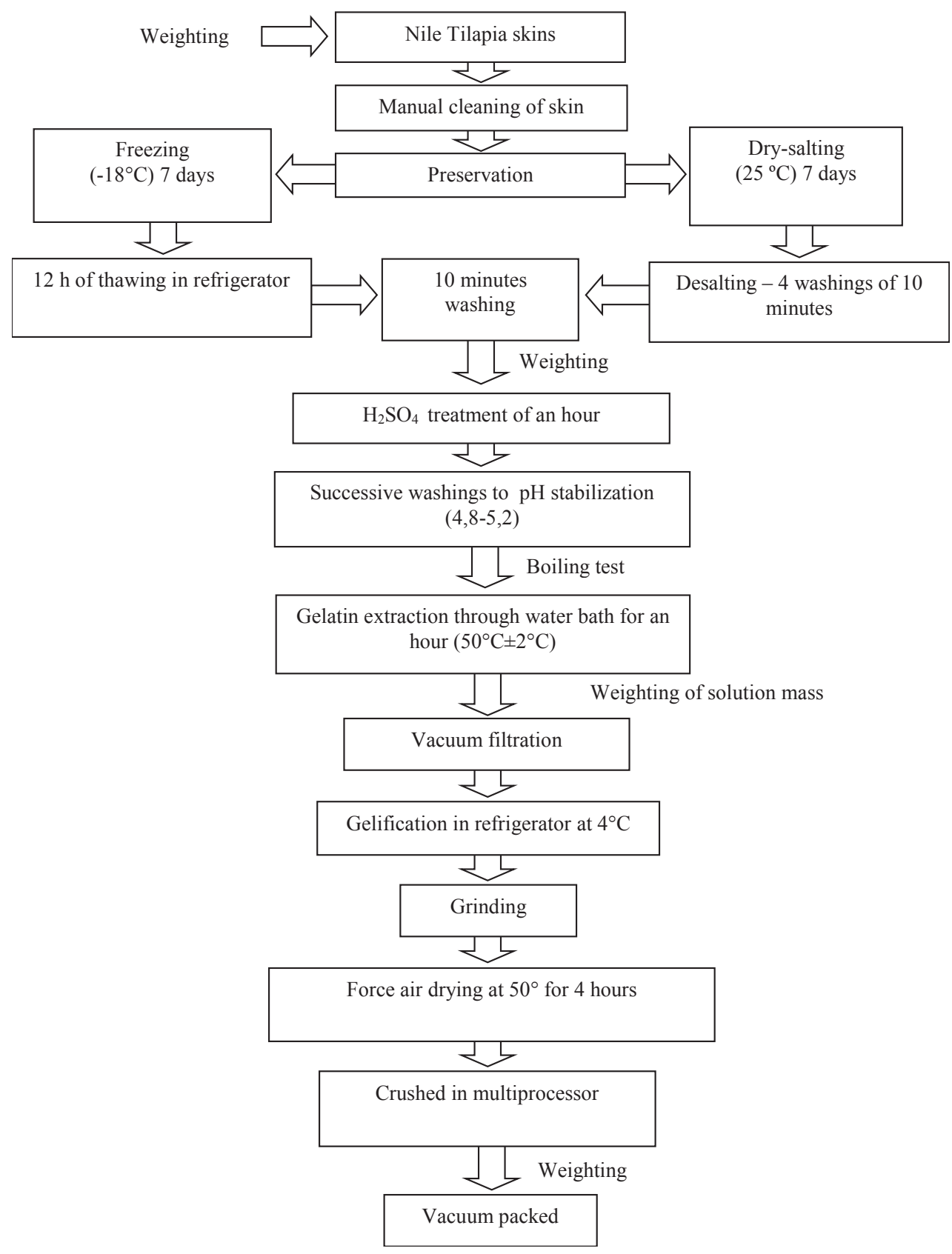

The composition of amino acids was determined with the Waters-PICO-TAGaminoacidauto-analyzer using high-performance liquid chromatographer (Waters 501, measuring 250x4.6mm) equipped with amino acid analyzing software. Each sample was hydrolyzed with $6 \mathrm{~N}$ hydrochloric acid at $110^{\circ} \mathrm{C}$ for 24 hours (WHITE et al., 1986).
Hydroxyproline content was determined by hydrolysis of the gelatin solution in hydrochloric acid with boiling under constant reflux, hydrated and diluted. It was then oxidized with hydrogen peroxide and measured by spectrophotometer (SPEIGHT, 2005). 
Viscosity was analyzed by measuring flow time of $100 \mu \mathrm{L}$ of gelatin solution $(6.67 \%)$ prepared at $60^{\circ} \mathrm{C}$, using a pipette viscosity-meter. Gel strength was obtained according to the British Standard (BS 757:1975) by texture analyzer TAX-T2 (Stable Micro System). The color of the gelatin solution was analyzed with a Hunter Ultrascan Sphere Spectrocolorimeter (Minolta Cr-300 series), using the $\mathrm{L}^{*}, \mathrm{a}^{*}$ and $\mathrm{b}^{*}$ scale, following methods outlined by Hunter (1975).

The experimental design was completely randomized and was comprised of two treatments of six replicates each. Each set of treatments was comprised of either gelatin extracted from frozen skins or gelatin extracted from salted skins. Results for each of the parameters, including yield, centesimal and mineral composition, bloom, viscosity and color, were analyzed by analysis of variance (ANOVA) and means were compared by F-test at $5 \%$ probability to determine significant differences using a Statistical Analysis System (SAS, SAS Inst. Inc. Cary, NC USA).

\section{Results and Discussion}

The overall yield of gelatin extracted from salted skins $\left(18 \mathrm{~g} \times 100 \mathrm{~g}^{-1}\right)$ was greater $(\mathrm{p}<0.05)$ than that extracted from frozen skin gelatin $\left(17 \mathrm{~g} \times 100 \mathrm{~g}^{-1}\right)$. Yield variations are due to the chemical composition of the skin, as well as the age of animals, species, extraction method (JONGJAREONRAK et al., 2006; MUYONGA et al., 2004), loss of extracted collagen or by incomplete hydrolysis (JAMILAH; HARVINDER, 2002), temperature or storage conditions of the skins. Lower yield rates may be related to the degree of covalent crosslinks, which may reduce the solubility of collagen (FOEGEDING et al., 1996). Possibly, freezing and thawing of the skins degraded the fibrillar structure of collagen, which may have led to the lower observed yield of gelatins obtained from frozen skins. FernándezDíaz et al. (2003) reported that freezing of fish skins negatively affected the molecular composition and rheological properties of the resulting gelatin. Apparently, the salt provided a greater protection to collagen fibers and enhanced the preservation of other properties of the skin. This resulted in an increased yield for the extraction, when compared to the preservation through freezing. Another observation of note is that salt in skins that remained after desalting washes may have interfered in the extraction of collagen. Chlorides are commonly used to solubilize myofibrillar proteins, thus helping to remove muscle that remains adhered to skin and may also predispose collagen for better extraction (GIMÉNEZ et al., 2005b). According to Giménez et al. (2005b), fish skins washed with $\mathrm{NaCl}$ resulted in a higher yield gelatin extractions $\left(16 \mathrm{~g} \times 100 \mathrm{~g}^{-1}\right)$ than unwashed skins using the same solutions $(13 \mathrm{~g}$ $\left.\times 100 \mathrm{~g}^{-1}\right)$.

Yields resulting from gelatin extractions in the current study were similar to those from frozen skins of the Nile tilapia performed by Bueno et al. (2011) and fresh skins of the Nile tilapia by Songchotikunpan et al. (2008), with yields of $18.3 \mathrm{~g}$ $\times 100 \mathrm{~g}^{-1}$ and $18.1 \mathrm{~g} \times 100 \mathrm{~g}^{-1}$, respectively.

Mean $\mathrm{pH}$ values for gelatin extracted from frozen and salted skins were 6.71 and 6.48, respectively, featuring type A gelatin with a $\mathrm{pH}$ range between 6.0 and 9.5, and type $\mathrm{B}$ gelatin with a $\mathrm{pH}$ range between 4.7 and 5.6 (NINAN et al., 2011).

There was no difference $(p>0.05)$ in the chemical composition of gelatins derived from frozen or salted skins (Table 1) with respect to humidity, crude protein, lipids and ashes. The two types of gelatin averaged $11.80 \mathrm{~g} \times 100 \mathrm{~g}^{-1}$ humidity, $85.06 \mathrm{~g} \times 100 \mathrm{~g}^{-1}$ protein, $0.03 \mathrm{~g} \times 100 \mathrm{~g}^{-1}$ lipids and $2.44 \mathrm{~g} \times 100 \mathrm{~g}^{-1}$ ashes. High crude protein rates in the gelatins and low rates for humidity, lipids and ashes, reveal the efficient removal of nutrients during the collagen extraction and gelatin preparation processes, and were also reported by both Jongjareonrak et al. (2010) and Silva et al. (2014). Variations in the chemical composition of gelatin mainly occurs as a result of differences in 
extraction methods and the protein composition of skins (GÓMEZ-GUILLÉN et al., 2011). Gelatin extracted from the skins of Rachycentron canadum and croaker revealed $88 \mathrm{~g} \times 100 \mathrm{~g}^{-1}$ crude protein
(SILVA et al., 2014). Songchotikunpan et al. (2008) reported $7.3 \mathrm{~g} \times 100 \mathrm{~g}^{-1}$ humidity, $89.4 \mathrm{~g} \times 100 \mathrm{~g}^{-1}$ protein, $0.3 \mathrm{~g} \times 100 \mathrm{~g}^{-1}$ lipids and $0.4 \mathrm{~g} \times 100 \mathrm{~g}^{-1}$ ashes in the gelatin from the skins of Nile tilapia.

Table 1. Chemical composition and mineral content of gelatin extracted from Nile tilapia skins.

\begin{tabular}{|c|c|c|c|c|}
\hline & \multicolumn{2}{|c|}{ Gelatin } & \multirow[b]{2}{*}{ F-Test } & \multirow[b]{2}{*}{ CV $(\%)$} \\
\hline & Frozen skins & Salted skins & & \\
\hline \multicolumn{5}{|l|}{ Chemical composition } \\
\hline Moisture (g.100g-1) & $11.92 \pm 2.78$ & $11.68 \pm 1.01$ & $0.03^{\mathrm{ns}}$ & 16.79 \\
\hline Protein $\left(\right.$ g. $\left.100 \mathrm{~g}^{-1}\right)$ & $84.47 \pm 5.59$ & $85.65 \pm 2.31$ & $0.18^{\mathrm{ns}}$ & 4.77 \\
\hline Fat $\left(\mathrm{g} .100 \mathrm{~g}^{-1}\right)$ & $0.04 \pm 0.03$ & $0.02 \pm 0.24$ & $2.72^{\mathrm{ns}}$ & 10.95 \\
\hline $\operatorname{Ash}\left(\right.$ g. $\left.100 g^{-1}\right)$ & $2.37 \pm 0.55$ & $2.51 \pm 0.29$ & $0.21^{\mathrm{ns}}$ & 17.30 \\
\hline \multicolumn{5}{|l|}{ Minerals } \\
\hline Calcium (mg.100g $\left.{ }^{-1}\right)$ & $117.17 \pm 10.77$ & $106.64 \pm 36.56$ & $45.76^{\mathrm{ns}}$ & 32.28 \\
\hline Iron $\left(\mathrm{g} .100 \mathrm{~g}^{-1}\right)$ & $0.27 \pm 0.08$ & $0.50 \pm 0.04$ & $2.50 *$ & 69.92 \\
\hline
\end{tabular}

ns not significant $(\mathrm{p}>0.05)$ by $\mathrm{F}$ test. $*$ Significant $(\mathrm{p}<0.05)$ by $\mathrm{F}$ test.

Similar rates were observed regarding the ash content of frozen $\left(2.37 \mathrm{~g} \times 100 \mathrm{~g}^{-1}\right)$ and salted $\left(2.51 \mathrm{~g} \times 100 \mathrm{~g}^{-1}\right)$ skins. The minor differences were likely due to the fact that the latter underwent successive washings to remove salt excess, which may have affected the composition of the gelatin. However, ash rates were below the maximum limits recommended for gelatin at $2.6 \mathrm{~g} \times 100 \mathrm{~g}^{-1}(\mathrm{JONES}$, 1977).

In the case of minerals (Table 1), the calcium content of both frozen and salted skins was similar $(p>0.05)$ even though levels of iron were significantly higher $(\mathrm{p}<0.05)$ in gelatin derived from salted skins $\left(0.50 \mathrm{~g} \times 100 \mathrm{~g}^{-1}\right)$ when compared to that from frozen $\left(0.27 \mathrm{~g} \times 100 \mathrm{~g}^{-1}\right)$. As a rule, the mineral composition of gelatins is similar to that of skins. The current study showed that the salted skin preservation method affected levels of iron in skin derived gelatin. Contrasting rates were reported for herrings, in which the salting process decreased observed levels of several minerals (Ca, P, Mg, K, $\mathrm{Cu}, \mathrm{Zn}, \mathrm{Se}$ and $\mathrm{Fe}$ ) when compared to the in natura prime matter (POLAK-JUSZCZAK, 2016).
Twenty-three fatty acids were detected in frozen and salted tilapia skins, but merely three were found in gelatins (Table 2). Several fatty acids had high concentrations in skins and in gelatins, with special reference to palmitic (16:0), stearic (18:0) and oleic $(18: 1 n-9)$ acids. Levels of fatty acids in gelatins were lower than those in skins, differences which were likely due to the hydrolysis process of fatty acids in skins. Further, gelatin lipid content from both groups $\left(0.03 \mathrm{~g} \times 100 \mathrm{~g}^{-1}\right.$ and $\left.0.02 \mathrm{~g} \times 100 \mathrm{~g}^{-1}\right)$ could be considered fat-free due to observed values that were lower than $0.5 \mathrm{~g} \times 100 \mathrm{~g}^{-1}$ rates (CHEOW et al., 2007).

Although salted skins have an accumulation of polyunsaturated fatty acids (PUFAs), they were not detected in gelatins. Gelatins from salted skins had a greater accumulation of saturated fatty acids (SFAs) and a lower amount of monounsaturated fatty acid (MUFA) when compared to gelatins from frozen skins, demonstrating the composition of skin fatty acids can affect gelatin content. Tilapia skins stored in ice for 18 days had $36.30 \mathrm{~g} \times 100 \mathrm{~g}^{-1}$ SFAs, $35.67 \mathrm{~g}$ $\times 100 \mathrm{~g}^{-1}$ MUFAs and $23.79 \mathrm{~g} \times 100 \mathrm{~g}^{-1}$ PUFAs (SAELEAW et al., 2013), which are rates similar to those found in the current study. 
Table 2. Composition of fatty acids $\left(\mathrm{g} \times 100 \mathrm{~g}^{-1}\right)$ in gelatins and skins of Nile tilapia preserved by either freezing or dry-salting methods.

\begin{tabular}{|c|c|c|c|c|}
\hline \multirow[b]{2}{*}{ Fatty acids } & \multicolumn{2}{|c|}{ Skins } & \multicolumn{2}{|c|}{ Gelatin } \\
\hline & Frozen & Salted & Frozen & Salted \\
\hline $14: 00$ & 2.10 & 2.29 & & \\
\hline $14: 1 \mathrm{n}-9$ & 0.22 & 0.23 & & \\
\hline $16: 00$ & 24.69 & 24.24 & 45.12 & 46.67 \\
\hline $16: 1 n-9$ & 0.57 & 0.62 & & \\
\hline $16: 1 n-7$ & 4.76 & 4.61 & & \\
\hline $16: 1 n-5$ & 0.20 & 0.20 & & \\
\hline 17:00 & 0.40 & 0.41 & & \\
\hline $17: 1 \mathrm{n}-9$ & 0.21 & 0.24 & & \\
\hline 18:00 & 8.54 & 8.69 & 18.90 & 29.16 \\
\hline 18:1n-9 & 33.46 & 30.82 & 35.96 & 24.15 \\
\hline $18: 1 n-7$ & 3.42 & 3.98 & & \\
\hline $18: 2 n-6$ & 9.54 & 10.14 & & \\
\hline $18: 3 n-6$ & 0.50 & 0.48 & & \\
\hline 20:00 & 0.54 & 0.56 & & \\
\hline $18: 3 n-3$ & 2.31 & 2.09 & & \\
\hline 20:1n-9 & 0.56 & 0.48 & & \\
\hline 21:00 & 0.22 & 0.24 & & \\
\hline $20: 2 n-6$ & 0.58 & 0.70 & & \\
\hline $20: 3 n-6$ & 1.60 & 2.63 & & \\
\hline $20: 5 n-3$ & 0.35 & 0.43 & & \\
\hline 24:1n-9 & 0.83 & 1.09 & & \\
\hline $22: 4 n-3$ & 0.75 & 0.95 & & \\
\hline $22: 6 n-3$ & 0.74 & 0.75 & & \\
\hline Sum of saturated fatty acids (SFA) & 36.49 & 36.43 & 64.02 & 75.83 \\
\hline Sum of monounsaturated fatty acids & 44.23 & 42.27 & 35.96 & 24.15 \\
\hline Sum of polyunsaturated fatty acids (PUFA) & 16.37 & 18.17 & & \\
\hline PUFA/SFA ratio & 0.45 & 0.50 & & \\
\hline Sum of n-3 fatty acids & 4.15 & 4.22 & & \\
\hline Sum of n-6 fatty acids & 12.22 & 13.95 & & \\
\hline
\end{tabular}

Table 3 shows the composition of amino acids of skins and gelatins. Glycine, alanine, proline, arginine and glutamic acid are the amino acids detected in skins and gelatins in high proportions. The composition of amino acids in gelatins is mainly determined by species (ALFARO et al., 2015).

Glycine was the amino acid with the highest abundance in gelatins, a finding corroborated by
Jongjareonrak et al. (2010). This is due to the type of structure forming the collagen chain, where at every two amino acid positions, a glycine residue is present within the collagen helix, followed by proline and hydroxyproline (NELSON; COX, 2011).

Hydroxyproline levels in gelatin extracted from salted and frozen skins of Nile tilapia were $8.76 \mathrm{~g}$ 
$\times 100 \mathrm{~g}^{-1}$ and $8.71 \mathrm{~g} \times 100 \mathrm{~g}^{-1}$, respectively. Amino acid levels are proportional to the resistance of gelatin gel (BENJAKUL et al., 2012). Proline and hydroxyproline are particularly involved in gel formation and determine the rheological properties and thermal stability of gelatin. The greater the proline and hydroxyproline content of gelatin, the greater its susceptibility for the formation of more compact helices and, consequently, the higher its melting temperatures and the better its viscoelastic properties (HAUG et al., 2004). Gelatin from the skin of the fish Pangasianodon gigas revealed 87 hydroxyproline residues per 1000 amino acids (JONGJAREONRAK et al., 2010), whereas gelatins extracted from the skin of the tilapia contained 79 hydroxyproline residues per 1000 amino acids (SARABIA et al., 2000).

Commercial gelatins from mammal and tuna skin contained 113 and 119 alanine, 342 and 336 glycine and 127 and 107 proline residues per 1000 amino acid residues, respectively (GÓMEZ-ESTACA et al., 2009).

Table 3. Amino acids in Nile tilapia gelatin and skins preserved by both freezing and dry-salt methods.

\begin{tabular}{lcccc}
\hline \multirow{2}{*}{ Amino acids } & \multicolumn{2}{c}{ Skins } & \multicolumn{2}{c}{ Gelatin } \\
\cline { 2 - 5 } & Frozen & Salted & Frozen skins & Salted skins \\
\hline Aspartic acid & 18.4 & 17.0 & 54.8 & 53.2 \\
Glutamic Acid & 29.8 & 27.6 & 95.6 & 92.8 \\
Serine & 11.1 & 9.8 & 34.0 & 33.1 \\
Glycine & 67.6 & 58.1 & 225.2 & 222.0 \\
Histidine & 2.7 & 2.5 & 7.1 & 6.5 \\
Arginine & 26.6 & 23.3 & 83.5 & 82.0 \\
Threonine & 8.5 & 7.8 & 25.2 & 24.5 \\
Alanine & 30.2 & 26.3 & 100.7 & 100.4 \\
Proline & 38.3 & 32.5 & 125.9 & 123.7 \\
Tyrosine & 2.3 & 2.3 & 4.4 & 4.3 \\
Valine & 70.0 & 6.2 & 18.8 & 17.1 \\
Methionine & 5.5 & 4.8 & 16.7 & 16.5 \\
Cystine & 3.3 & 1.9 & 7.0 & 3.7 \\
Isoleucine & 4.1 & 3.7 & 9.9 & 9.6 \\
Leucine & 9.9 & 8.8 & 25.5 & 25.1 \\
Phenylalanine & 6.7 & 5.9 & 19.2 & 19.0 \\
Lysine & 10.3 & 9.3 & 31.2 & 30.7 \\
Total & 282.3 & 247.8 & 884.7 & 864.0 \\
\hline
\end{tabular}

Residues/1000 amino acid residues.

When viscosity and gel strength were assessed, gelatin viscosity from salted skins (19.02 mPas) was significantly $(p<0.05)$ greater compared to gelatin from frozen skins $(9.16 \mathrm{mPas})$ (Figure 2a). The difference is directly proportional to rates of gel strength or bloom, which was significantly $(\mathrm{p}<0.05)$ greater $(200.10 \mathrm{~g})$ in the gelatin from salted skins than in the gelatin from frozen ones $(12.70 \mathrm{~g})$ (Figure 2b). Therefore, skin preservation by the dry salt method provides gelatins with greater viscosity rates and greater gel strength.

Gelatins with low viscosity rates produce weak gels, whereas high viscosity rates provide consistent and extensible ones (SILVA et al., 2014). The above is supported by this analysis showing that gelatin with greater viscosity also had greater gel strength. Gel strength is the most relevant functional characteristic of gelatin and varies depending 
on concentration, conditions of preparation and the presence of other hydrocolloids (SILVA et al., 2014). As a rule, higher rates of gel strength correspond to higher quality gelatin (BUENO et al., 2011). Commercially usable gelatin strength values fall between $100 \mathrm{~g}$ and 300g (GÓMEZ-GUILLÉN et al., 2011). Results show that the skin preservation method affects the gel strength of fish gelatins, possibly due to the degradation of alpha chains of collagen (FERNÁNDEZ-DÍAZ et al., 2003; LIU et al., 2008).

Whereas collagen is composed of three alpha chains, gelatin is comprised of alpha chains, beta components (dimers of alpha chains), high molecular weight polymers including gamma components (trimmers of alpha chains) and some fragments of smaller molecular weight (LIU et al., 2008). Gelatins with greater amounts of alpha chains have higher gel strength (SHI et al., 2002). It seems that skin freezing at $-18^{\circ} \mathrm{C}$ for seven days degraded alpha chains, resulting in reduced gel strength. Gelatin from the fresh skin of the fish Platichthys flesus has a greater gel strength when compared to gelatins from frozen skins $\left(-12\right.$ and $\left.-20^{\circ} \mathrm{C}\right)$, due to fragments of greater molecular weight and greater proportions of alpha versus beta and gamma in gelatins derived from fresh skins. On the other hand, gelatins from frozen skins had more fragments with low molecular weight and smaller amounts proportions of components alpha in relation to beta and gamma (FERNÁNDEZ-DÍAZ et al., 2003). These were also trends that were confirmed by data in the current analysis (Figure 2).

On the other hand, the dry salt preservation method may improve gel strength when compared to that with fresh skins, as this study demonstrates. Liu et al. (2008) showed that the drying of skins provided gelatins with greater gel strength $(256 \mathrm{~g})$ when compared with gelatin from frozen skins (246g) of Ictaluru spunctaus. The improvement is due to the higher proportion alpha chains observed in the gelatin of dry skins. The authors found that fresh skins have many fragments of low molecular weight, providing a lower gel strength when compared to the gelatin extracted from dried skins (LIU et al., 2008). However, Giménez et al. (2005a) did not detect any difference in the gel strength of gelatins from Solea vulgaris skins stored for 160 days employing air-drying, ethanol, ethanolglycerol mix and sea salt.

Figure 2. Data showing viscosity (a) and bloom (b) of gelatin extracted from frozen and salted skins of Nile tilapia. Mean values of six determinations $( \pm \mathrm{SD})$ are given. Different letters indicate significant difference $(\mathrm{p}<0.05)$ by F-test.

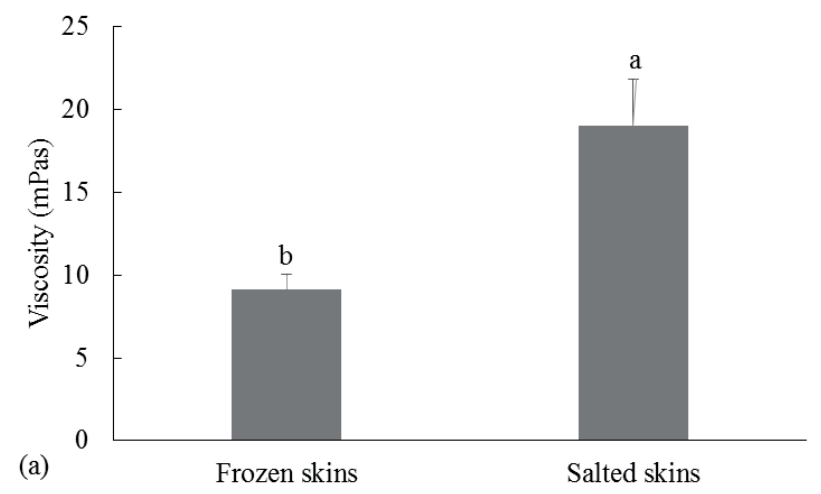

There was no difference $(\mathrm{p}>0.05)$ in luminosity averages $\left(\mathrm{L}^{*}\right)$ when the color of powder gelatins extracted from frozen and salted skins of the Nile

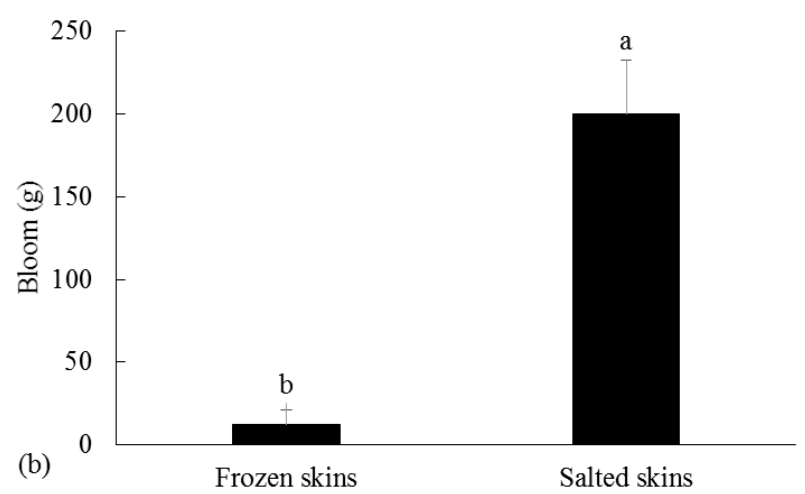

tilapia was compared (Table 4). However, differences $(p>0.05)$ in averages was seen between chromes a* and $b^{*}$, where gelatin extracted from salted skins 
had the greatest means for chrome $\mathrm{a}^{*}(0.56)$ and $\mathrm{b}^{*}$ (9.23). Results show that gelatin from frozen skins had a more greenish color when compared to that of gelatin extracted from salted skins. Further, gelatin extracted from salted skins had a deeper yellowish color when compared to that of gelatin from frozen skins. Gelatin color depends on extracted prime matter and on whether it involves first, second or other extractions (NINAN et al., 2011). For instance, gelatin from the skin of the African catfish (Clarias gariepinus) revealed rates of 57.60 for luminosity, 0.23 for chrome $\mathrm{a}^{*}$ and 2.66 for chrome $\mathrm{b}^{*}$ and were a light yellowish color (ALFARO et al., 2014). The color of most commercial gelatins ranges between light yellow and dark amber (JAMILAH; HARVINDER, 2002). It should be understood that the color of gelatin does not influence its functional characteristics (CHEOW et al., 2007).

Table 4. Color of dry gelatin extracted from Nile tilapia skins.

\begin{tabular}{cccccc}
\hline & \multicolumn{2}{c}{ Gelatin } & & \\
\cline { 2 - 3 } & Frozen skins & Salted skins & & F Test & CV (\%) \\
\hline $\mathrm{L}^{*}$ & $37.54 \pm 4.05$ & $39.67 \pm 2.25$ & & $1.05^{\text {ns }}$ & 8.50 \\
$\mathrm{a}^{*}$ & $-1.10 \pm 0.56$ & $0.56 \pm 0.63$ & & $18.85^{*}$ & 8.50 \\
$\mathrm{~b}^{*}$ & $5.27 \pm 1.60$ & $9.23 \pm 1.47$ & & $16.50^{*}$ & 21.22 \\
\hline
\end{tabular}

$\mathrm{L}^{*}$ : luminosity $\mathrm{a}^{*}$ : intensity of red color; $\mathrm{b}^{*}$ : intensity of yellow color.

${ }^{\mathrm{n}}$ Not significant $(\mathrm{p}>0.05)$ by F-test. *Significant $(\mathrm{p}<0.05)$ by F-test.

\section{Conclusions}

Gelatin extracted from the dry-salted skins of the Nile tilapia had better yield, better rheological properties (gel strength and viscosity), higher iron levels and better color in relation to gelatin obtained from frozen Nile tilapia skins. In fact, sodium chloride is a highly efficient preserver for skins and, consequently, results in the production of quality gelatins from the skins of the Nile tilapia.

\section{Declaration of conflicting interests}

The author(s) declared no potential conflicts of interest with respect to the research, authorship, and/or publication of this article.

\section{Acknowledgements}

The authors would like to thank the National Council for Scientific and Technological Development (CNPq), Embrapa (Brazilian Agricultural Research Corporation) - Project
Aquabrasil, MPA (Ministry of Fisheries and Aquaculture) and Gelita Company of Brazil, for their funding of current experiment.

\section{References}

ALFARO, A. T.; BALBINOT, E.; WEBER, C. I.; TONIAL, I. B.; MACHADO-LUNKES, A. Fish gelatin: characteristics, functional properties, applications and future potentials. Food Engineering Reviews, New York, v. 7 , n. 1 , p. $33-44$, 2015. DOI: 10.1007/s12393-0149096-5

ALFARO, A. T.; BILUCA, F. C.; MARQUETTI, C.; TONIAL, I. B.; SOUZA, N. E. African catfish (Clarias gariepinus) skin gelatin: extraction optimization and physical-chemical properties. Food Research International, Barking, v. 65, n. C, p. 416-422, 2014. DOI: 10.1016/j.foodres.2014.05.070

ASSOCIATIONS OF OFFICIAL ANALYTICAL CHEMISTS - AOAC. Official methods of analyses of the association of analytical chemists. Washington: AOAC, 2005.

BENJAKUL, S.; KITTIPHATTANABAWON, P.; REGENSTEIN, J. M. Fish gelatin. In: SIMPSON, B. K. (Ed.). Food biochemistry and food processing. Oxford: John Wiley and Sons, 2012. p. 388-405. 
BLIGH, E. G.; DYER, W. J. A rapid method of total lipid extraction and purification. Canadian Journal of Biochemistry and Physiology, Ottawa, v. 37, n. 8, p. 911917, 1959. DOI: 10.1139/059-099

BORDIGNON, A. C.; FRANCO, M. L. R. S.; GASPARINO, E.; YAJIMA, E. M.; VESCO, A. P. D.; VISENTAINER, J. V.; MIKCHA, J. M. G. Utilization of frozen and salted Nile tilapia skin for batch-processed gelatin extraction. Revista Brasileira de Zootecnia, Viçosa, MG, v. 41, n. 3, p. 473-478, 2012. DOI: 10.1590/ S1516-35982012000300001

BUENO, C. M.; ALVIM, I. D.; KOBERSTEIN, T. C. R. D.; PORTELLA, M. C.; GROSSO, C. Produção de gelatina de pele de tilápia e sua utilização para obtenção de micropartículas contendo óleo de salmão. Brazilian Journal of Food Technology, Campinas, v. 14, n. 1, p. 65-73, 2011. DOI: 10.4260/BJFT2011140100009

CHEOW, C. S.; NORIZAH, M. S.; KYAW, Z. Y.; HOWELL, N. K. Preparation and characterization of gelatins from the skins of sin croaker (Johnius dussumieri) and shortfin scad (Decapterusmacrosoma). Food Chemistry, London, v. 101, n. 1, p. 386-391, 2007. DOI: 10.1016/j.foodchem.2006.01.046

CHO, S. M.; GU, Y. S.; KIM, S. B. Extracting optimization and physical properties of yellowfin tuna (Thunnus albacares) skin gelatin compared to mammalian gelatins. Food Hydrocolloids, Lancaster, v. 19, n. 2, p. 221-229, 2005. DOI: 10.1016/j.foodhyd.2004.05.005

EIJSINK, L. M.; KROM, M. D.; LANGE, G. J. The use of sequential extraction techniques for sedimentary phosphorus in eastern Mediterranean sediments. Marine Geology, Amsterdam?, v. 139, n. 1-4, p. 147-155, 1997. DOI: 10.1016/S0025-3227(96)00108-9

FERNÁNDEZ-DÍAZ, M. D.; MONTERO, P.; GÓMEZGUILLÉN, M. C. Effect of freezing fish skins on molecular and rheological properties of extracted gelatin. Food Hydrocolloids, Lancaster, v. 17, n. 3, p. 281-286, 2003. DOI: $10.1016 / \mathrm{S} 0268-005 \mathrm{X}(02) 00078-4$

FOEGEDING, E.; LANIER, T. C.; HULTIN, H. O. Characteristics of edible muscle tissue. In: FENNEMA, O. R. (Ed.). Food chemistry. New York: Marcel Dekker, 1996. 1144 p.

GIMÉNEZ, B.; GÓMEZ-GUILLÉN, M. C.; MONTERO, P. Storage of dried fish skins on quality characteristics of extracted gelatin. Food Hydrocolloids, Lancaster, v. 19, n. 6, p. 958-963, 2005a. DOI: 10.1016/j. foodhyd.2004.12.012

GIMÉNEZ, B.; GÓMEZ-GUILLÉN, M. C.; MONTERO, P. The role of salt washing of fish skins in chemical and rheological properties of gelatin extracted. Food Hydrocolloids, Lancaster, v. 19, n. 6, p. 951-957, 2005 b. DOI: 10.1016/j.foodhyd.2004.09.012

GÓMEZ-ESTACA, J.; MONTERO, P.; FERNÁNDEZMARTÍN, F.; GÓMEZ-GUILLÉN, M. C. Physicochemical and film-forming properties of bovinehide and tuna-skin gelatin: a comparative study. Journal of Food Engineering, Essex, v. 90, n. 4, p. 480-486, 2009. DOI: 10.1016/j.jfoodeng.2008.07.022

GÓMEZ-GUILLÉN, M. C.; GIMÉNEZ, B.; LÓPEZCABAllero, M. A.; MONTERO, M. P. Functional and bioactive properties of collagen and gelatin from alternative sources: a review. Food Hydrocolloids, Lancaster, v. 25, n. 8, p. 1813-1827, 2011. DOI: 10.1016/j. foodhyd.2011.02.007

HAUG, J. I.; DRAGET, I. K.; SMIDROD, O. Physical and rheological properties of fish gelatin compared to mammalian gelatin. Food Hydrocolloids, Lancaster, v. 18 , n. 2, p. 203-213, 2004. DOI: 10.1016/S0268005X(03)00065-1

HOSSEINI, S. F.; REZAEI M.; ZANDI, M.; GHAVI, F. F. Preparation and functional properties of fish gelatinchitosan blend edible films. Food Chemistry, London, v. 136, n. 3, p. 1490-1495, 2013. DOI: 10.1016/j. foodchem.2012.09.081

HUNTER, R. S. The measurement of appearance. New York: John Wiley and Sons, 1975. 432 p.

INTARASIRISAWAT, R.; BENJAKUL, S.; VISESSANGUAN, W.; PRODPRAN, T.; TANAKA, M.; HOWELL, N. K. Autolysis study of bigeye snapper (Priacanthus macracanthus) skin and its effect on gelatin. Food Hydrocolloids, Lancaster, v. 21, n. 4, p. 537-544, 2007. DOI: 10.1016/j.foodhyd.2006.05.012

INTERNATIONAL ORGANIZATION FOR STANDARDIZATION - ISO 5509. Animal and vegetable fats and oils - Preparation of methyl esters of fatty acids. Geneve: ISO, 1978. 6 p.

JAMILAH, B.; HARVINDER, K. G. Properties of gelatins from skins of fish -black tilapia (Oreochromis mossambicus) and red tilapia (Oreochromis niloticus). Food Chemistry, London, v. 77, n. 1, p. 81-84, 2002. DOI: /10.1016/S0308-8146(01)00328-4

JOHNSTON-BANKS, F. A. Gelatin. In: HARRIS, P. (Ed.). Food gels. London: Elsevier Applied Science, 1990. p. 233-289.

JONES, N. R. Uses of gelatin in edible products. In: WARD, A. G.; COURTS, A. (Ed.). The science and technology of gelatins. New York: Academic Press, 1977. p. 365-394. 
JONGJAREONRAK, A.; RAWDKUEN, S.; CHAIJAN, M.; BENJAKUL, S.; OSAKO, K.; TANAKA, M. Chemical compositions and characterization of skin gelatin from farmed giant catfish (Pangasianodon gigas) LWT - Food Science Technology, Amsterdam, v. 43, n. 1, p. 161-165, 2010. DOI: 10.1016/j.lwt.2009.06.012

JONGJAREONRAK, A.; SOOTTAWAT, B.; WONNOP, V.; TANAKA, M. Skin gelatin from bigeye snapper and brownstripe red snapper: chemical compositions and effect of microbial transglutaminase on gel properties. Food Hydrocolloids, Lancaster, v. 20, n. 8, p. 1216-1222, 2006. DOI: 10.1016/j.foodhyd.2006.01.006

KARIM, A. A.; BHAT, R. Fish gelatin: properties; challenges; and prospects as an alternative to mammalian gelatins. Food Hydrocolloids, Lancaster, v. 23, n. 3, p. 563-576, 2009. DOI: 10.1016/j.foodhyd.2008.07.002

LIU, H.; LI, D.; GUO, S. Rheological properties of channel catfish (Ictalurus punctaus) gelatin from fish skins preserved by different methods. LWT - Food Science and Technology, Amsterdam, v. 41, n. 8, p. 14251430, 2008. DOI: 10.1016/j.1wt.2007.09.006

LIU, S.; FAN, W.; ZHONG, S.; MA, C.; LI, P.; ZHOU, K.; ZHU, M. Quality evaluation of tray-packed tilapia fillets stored at $0 \mathrm{C}$ based on sensory; microbiological; biochemical and physical attributes. African Journal of Biotechnology, Nairobi, v. 9, n. 5, p. 692-701, 2010. DOI: 10.5897/AJB09.1369

MUYONGA, J. H.; COLE, C. G. B.; DUODU, K. G. Extraction and physicochemical characterization of nile perch (Lates niloticus) skin and bone gelatin. Food Hydrocolloids, Lancaster, v. 18, n. 4, p. 581-592, 2004. DOI: 10.1016/j.foodhyd.2003.08.009

NAGARAJAN, M.; BENJAKUL, S.; PRODPRAN, T.; SONGTIPYA, P.; KISHIMURA, H. Characteristics and functional properties of gelatin from splendid squid (Loligo formosana) skin as affected by extraction temperatures. Food Hydrocolloids, Lancaster, v. 29, n. 2, p. 389-397, 2012. DOI: 10.1016/j.foodhyd.2012.04.001

NELSON, D. L.; COX, M. M. Princípios de bioquímica de Lehninger. Porto Alegre: Artmed, 2011. 1304 p.

NINAN, G.; JOSE, J.; ABUBACKER, Z. Preparation and characterization of gelatin extracted from the skins of rohu (Labeo rohita) and common carp (Cyprinus carpio). Journal of Food Processing and Preservation, Westport, v. 35 , n. 2 , p. $143-162$, 2011. DOI: $10.1111 /$ j.17454549.2009.00467.x

POLAK-JUSZCZAK, L. Effects of processing methods on the content of minerals in fish products. Journal of Elementology, Olszytn, v. 21, n. 2, p. 461-470, 2016. DOI: $10.5601 /$ jelem.2015.20.3.890
SAE-LEAW, T.; BENJAKUL, S.; GOKOGLU, N.; NALINANON, S. Changes in lipids and fishy odour development in skin from Nile tilapia (Oreochromis niloticus) stored in ice. Food Chemistry, London, v. 141 , n. 3, p. 2466-2472, 2013. DOI: $10.1016 / j$. foodchem.2013.05.049

SARABIA, A. I.; GÓMEZ-GUILLÉN, M. C.; MONTERO, P. The effect of added salts on the viscoelastic properties of fish skin gelatin. Food Chemistry, London, v. 70, n. 1, p. 71-76, 2000. DOI: 10.1016/S0308-8146(00)00073-X

SHI J.; CHEN L.; WANG Y. A study of the gel strength change of photogelatin in dependence on their content of $\alpha$ components. Imaging Science and Photochemistry, Pequim, v. 20, n. 6, p. 462-467, 2002. DOI: $10.7517 /$ j. issn.1674-0475.2002.06.462

SILVA, R. S.; BANDEIRA, S. F.; PINTO, L. A. Characteristics and chemical composition of skins gelatin from cobia (Rachycentron canadum). LWT - Food Science and Technology, Amsterdam, v. 57, n. 2, p. 580585, 2014. DOI: 10.1016/j.lwt.2014.02.026

SONGCHOTIKUNPAN, P.; TATTIYAKUL， J.; SUPAPHOL, P. Extraction and electrospinning of gelatin from fish skin. International Journal of Biological Macromolecules, Amsterdam, v. 42, n. 3, p. 247-255, 2008. DOI: 10.1016/j.ijbiomac.2007.11.005.

SPEIGHT, J. G. Lange's handbook of chemistry. New York: McGraw-Hill, 2005. 1623 p.

STRÁNSKY, K.; JURSÍK, T.; VÍTEK, A. Standard equivalent chain length values of monoenic and polyenic (methylene interrupted) fatty acids. Journal of Separation Science, Weinheim, v. 20, n. 3, p. 143-158, 1997. DOI: /10.1002/jhrc. 1240200305

TABARESTANI, H. S.; MAGHSOUDLOU, Y.; MOTAMEDZADEGAN, A.; MAHOONAK, A. S. Optimization of physico-chemical properties of gelatin extracted from fish skin of rainbow trout (Onchorhynchus mykiss). Bioresource Technology, Miramar, v. 101, n. 15, p. 6207-6214,2010.DOI: 10.1016/j.biortech.2010.02.071

WHITE, J. A.; HART, R. J.; FRY, J. An evaluation of the waters pico-tag system for the amino-acid-analysis of food materials. Journal of Automatic Chemistry, New York, v. 8, n. 4, p. 170-177, 1986. DOI: $10.1155 /$ S1463924686000330

ZHANG, Z.; LI, G.; SHI, B. Physicochemical properties of collagen; gelatin and collagen hydrolysate derived from bovine limed split wastes. Journal of the Society of Leather Technologists and Chemists, London, v. 90, n. 1, p. 23-28, 2005. 